\title{
UJI AKTIVITAS ANTIOKSIDAN FRAKSI ETER HASIL HIDROLISIS INFUSA DAUN BINAHONG (Anredera cordifolia (Ten.) Steenis) DENGAN METODE DPPH (1,1-DIPHENIL-2-PICRYLHYDRAZYL)
}

\section{ANTIOXIDANT ACTIVITY OF ETHER FRACTION OF HIDROLYSED INFUSE BINAHONG FOLIUM (Anredera cordifolia (Ten.) Steenis) WITH DPPH (1,1-DIPHENIL-2-PICRYLHYDRAZYL) METHOD}

\author{
Agustina Ardianti, Any Guntarti, Zainab \\ Fakultas Farmasi Universitas Ahmad Dahlan Yogyakarta \\ Jl. Prof. Dr. Soepomo SH, Yogyakarta, Telp. (0274) 379418 \\ Email: any_guntarti@yahoo.co.id.
}

\begin{abstract}
ABSTRAK
Antioksidan merupakan senyawa yang mampu menghambat laju oksidasi. Daun binahong mengandung flavonoid yang dapat mempunyai aktivitas sebagai antioksidan. Penelitian ini bertujuan untuk mengetahui besarnya aktivitas antioksidan fraksi eter hasil hidrolisis infusa daun Binahong dan mengetahui harga $\mathrm{EC}_{50}$ nya. Fraksi eter diperoleh dengan menghidrolisis infusa daun Binahong menggunakan larutan $\mathrm{HCl} 2 \mathrm{~N}$, selanjutnya difraksinasi dengan pelarut eter. Pengukuran aktivitas antioksidan dilakukan dengan metode DPPH menggunakan spektrofotometer. Panjang gelombang serapan maksimum 515,0 nm (quersetin) dan 514,0 nm (fraksi eter). Waktu operasinya 19 - 30 menit (quersetin) dan 19 - 29 menit (fraksi eter). Uji aktivitas penangkapan radikal bebas dilakukan dengan metode DPPH (1,1-difenil-2-pikrilhidrazil). Berkurangnya radikal DPPH dalam larutan menurunkan intensitas absorbansi dari sampel. Dari data persen penangkapan radikal bebas dapat dicari nilai $\mathrm{EC}_{50}$ (Effective Concentration). Hasil penelitian menunjukkan bahwa semua sampel uji mempunyai aktivitas penangkapan radikal bebas. Hasil uji menunjukkan bahwa nilai $\mathrm{EC}_{50}$ quersetin $(2,702 \pm 0,15)$ $\mu \mathrm{g} / \mathrm{ml}, \mathrm{EC}_{50}$ fraksi eter hasil hidrolisis infusa daun Binahong $(249,31 \pm 9,26) \mu \mathrm{g} / \mathrm{ml}$. Analisis menggunakan uji statistik Kruskall Wallis (taraf kepercayaan 95\%) dilanjutkan uji Mann Whitney menunjukkan adanya perbedaan yang signifikan antara sampel dan kontrol (quersetin).
\end{abstract}

Kata kunci: Daun Binahong (Anredera cordifolia (Ten.) Steenis), antioksidan, radikal bebas, DPPH.

\section{ABSTRACT}

Antioxidant is compounds which have abilities to inhibit oxidation rate. Anredera cordifolia folium consist of flavonoid which have activities as antioxidant. The purpose of this research was to know antioxidant activity at ether fraction of hydrolysed aquous extract of Binahong folium (Anredera cordifolia). Ether fraction was obtained by hydrolysing the infuse Binahong folium (Anredera cordifolia) with $\mathrm{HCl} 2 \mathrm{~N}$ then fractionated with ether and then evaporated. The antioxidant activity was measured by DPPH method using spectrophotometer. The maximum wavelength and operating time quercetin and samples were 515,0 $\mathrm{nm}$ (quersetin) and 514,0 nm (ether fraction), 19-30 minute (quersetin) and 19-29 minute (ether fraction). Scavenging activity test done with the DPPH method (1,1- dyphenyl-2-picrylhydrazyl). The decreasing of DPPH radical solution decreased the absorbant intensity. The percentage of radical scavenging activity was performed as EC $_{50}$ (Effective Concentration). The results indicated that both samples showed free radical scavenging activity with $\mathrm{EC}_{50}$ value for quercetin $(2,702 \pm 0,15) \mu \mathrm{g} / \mathrm{ml}$, and ether fraction of $(249,31 \pm 9,26) \mu \mathrm{g} / \mathrm{ml}$. Statistical analysis using Kruskall Wallis method with 95\% of confident level followed by Mann Whitney test 
giving evidence the results between samples and positive control (quercetin) are significantly difference.

Keywords: Binahong (Anredera cordifolia (Ten.) Steenis), antioxidant, free radical, DPPH.

\section{PENDAHULUAN}

Radikal bebas berperan dalam terjadinya suatu penyakit, karena radikal bebas mempunyai suatu elektron yang tidak berpasangan dipermukaan kulit luarnya sehingga dia berusaha mencari elektron dari jaringan-jaringan yang ada di dalam tubuh yang disusun oleh sel-sel. Dalam tubuh terdapat senyawa yang disebut antioksidan yang dapat berperan aktif dalam menanggulangi masalah kelebihan radikal bebas. Namun, hal ini tergantung terhadap pola hidup dan pola makan yang benar (Kumalaningsih, 2006).

Antisipasi terhadap terbentuknya radikal bebas dalam tubuh dapat dilakukan dengan mengubah dan mengatur pola makan yang benar atau mengkonsumsi makanan tambahan (supplement) yang dapat diperoleh di sekitar kita. Aneka buah dan sayuran dapat dimanfaatkan sebagai sumber bahan antioksidan untuk meredam radikal bebas (Hernani dan Rahardjo, 2005). Salah satu senyawa alam yang diketahui memiliki aktivitas antioksidan adalah flavonoid (Sunarni et al, 2007).

Tanaman Binahong (Anredera cordifolia, (Ten.) Steenis) merupakan salah satu jenis tumbuhan yang tersebar luas dan cukup terkenal di masyarakat Indonesia. Daun Binahong mengandung saponin, triterpenoid, minyak atsiri (Rachmawati, 2008) dan flavonoid quersetin (Yang et al, 2008). Adanya flavonoid kemungkinan besar daun Binahong dapat berkhasiat sebagai antioksidan (menangkap radikal bebas). Ditemukan adanya protein dengan BM besar pada Binahong (23kDa) yang diberi nama ancordin (Chuang et al, 2007). Pada hidrolisis asam ekstrak etanolik menghasilkan asam oleanolik (Moura-Lettset al, 2006).

Antioksidan merupakan senyawa yang mampu menghambat laju oksidasi. Antioksidan ini memiliki banyak komponen dan merupakan zat alami yang dihasilkan sendiri oleh tubuh atau didapat dari makanan yang kita makan. Antioksidan bekerja dengan cara menghentikan pembentukan radikal bebas, menetralisir serta memperbaiki kerusakan-kerusakan yang terjadi (Dalimartha dan Soedibyo, 1999). Radikal bebas merupakan atom atau melekul yang memiliki satu atau lebih elektron yang tidak berpasangan. Radikal bebas dianggap pasangan elektronnya. Radikal bebas dapat bereaksi dengan molekul sel tubuh dengan cara mengikat elektron dari melekul sel tersebut dan dapat menyebabkan reaksi berantai yang merusak tubuh (Hanasakti et.al., 1994).

Flavonoid adalah senyawa yang mengandung 15 atom karbon dalam inti dasarnya. Flavonoid tersusun dalam konfigurasi $\mathrm{C}_{6}-\mathrm{C}_{3}-\mathrm{C}_{6}$ yaitu dua cincin benzena yang dihubungkan oleh tiga atom karbon yang dapat atau tidak dapat membentuk cincin ketiga cincin itu masing-masing A,B, dan C.

Quersetin adalah salah satu zat aktif kelas flavonoid yang dijumpai pada tumbuhan dalam kadar tinggi. Quersetin (3',4'-dihidroksiflavonol) merupakan senyawa flavonoid dari kelompok flavonol. Senyawa flavon ini terdapat dalam banyak sayuran dan buah - buahan.

Dalam penelitian ini dilakukan uji kuantitatif dengan metode DPPH (1, 1-difenil-2pikrilhidrazil). DPPH adalah salah satu metode yang telah dikembangkan dalam aktivitas antioksidan. DPPH memiliki aktivitas penangkap radikal bebas yang tinggi dalam pelarut organik polar, seperti metanol atau etanol pada suhu kamar. Dalam uji DPPH, penangkapan radikal DPPH disertai dengan penurunan serapan pada panjang gelombang 515-517 nm (Suryanto et al, 2003).

\section{METODE PENELITIAN}

\section{Alat}

Timbangan analitik, glassware, blender, kompor, panci infusa, penangas air, termometer, kertas saring, kain flanel dan alat refluks, Spektrofotometer UV-Vis (Pharma Spec 
Shimadzu UV - 1700), mikro pipet, pipa kapiler, bejana pengembang, lampu UV $366 \mathrm{~nm}$.

\section{Bahan}

Bahan utama yang digunakan dalam penelitian ini adalah tanaman Binahong (Anredera cordifolia (Ten.) Steenis) yang diperoleh dari daerah Pacitan, Jawa Timur pada bulan April 2009. Bahan kimia yang digunakan untuk penelitian ini berderajad pro analisis, yaitu aquadest, $\mathrm{HCl}$, eter, $\mathrm{Na}_{2} \mathrm{SO}_{4}$ anhidrat, silika gel F 254, asam asetat glasial, butanol, uap ammonia, metanol absolut, asam fosfomolibdat, rutin, DPPH (1,1difenil-2-pikrilhidrazil).

\section{Jalannya Penelitian}

\section{Determinasi tanaman dan pembuatan simpisia}

Binahong (Anredera cordifolia (Ten.) Steenis) dilakukan berdasarkan buku Flora of Java (Van Steenis, 1997). Determinasi dilakukan di Laboraturium Biologi Universitas Ahmad Dahlan Yogyakarta. Daun Binahong (Anredera cordifolia (Ten.) Steenis) diambil yang telah tua yang warnanya hijau tua dan dikumpulkan, dicuci bersih pada air yang mengalir kemudian dikeringkan di bawah sinar matahari langsung dengan ditutup kain hitam. Setelah kering diblender sehingga diperoleh serbuk simplisia daun Binahong (Anredera cordifolia (Ten.) Steenis).

\section{Pembuatan infusa}

Daun Binahong sebanyak 50 gram dalam panci infusa ditambahkan aquades sampai $600 \mathrm{ml}$. Campuran dipanaskan di atas penangas air selama 15 menit dihitung dari suhu $90^{\circ} \mathrm{C}$ sambil sesekali diaduk. Campuran diserkai selagi panas, disaring melalui kain flanel dan disaring dengan kertas saring kemudian dipekatkan.

\section{Fraksinasi}

Larutan induk infusa yang diperoleh dihidrolisis dengan asam klorida $2 \mathrm{~N}$ sebanyak $100 \mathrm{ml}$, direfluks 1 jam, setelah pekatkan, dihidrolisis dan diekstraksi dengan eter sehingga didapatkan senyawa dalam fraksi eter dan senyawa dalam air asam. Fraksi eter dikumpulkan, diuapkan digunakan sebagai sampel.

\section{Uji pendahuluan adanya flavonoid}

Fraksi eter ditotolkan pada silika gel F 254, kemudian dikembangkan dengan menggunakan fase gerak n-butanol:asam asetat glasial:air $(4: 1: 5) \mathrm{v} / \mathrm{v}$ (fase atas).

\section{Uji aktivitas penangkapan radikal bebas dengan metode DPPH}

Uji aktivitas ini diawali dengan penentuan waktu operasi dan panjang gelombang serapan maksimum. Fraksi eter hasil hidrolisis infusa daun Binahong (Anredera cordifolia (Ten.) Steenis) dan quersetin yang telah dilarutkan dengan metanol absolut dengan berbagai konsentrasi $(1,0 \mathrm{ml})$, ditambah $1,0 \mathrm{ml}$ larutan pereaksi DPPH dalam tabung reaksi kering, dikocok homogen dan diinkubasi selama operating time, kemudian diamati absorbansinya pada panjang gelombang maksimum dengan spektrofotometer UV-Vis. Untuk kontrol negatif digunakan metanol 1,0 ml ditambah $1,0 \mathrm{ml}$ larutan pereaksi DPPH (Suryanto et al, 2003).

\section{Analisis data}

Dari data yang diperoleh dianalisis dengan menggunakan Rumus perhitungan sebagai berikut:

$\%$ Penangkapan $=\left[1-\frac{\left(A_{\left.\text {sampel pada } \lambda_{\text {maks }}\right)}\right.}{\left(A_{\left.\text {kontrol negatif pada } \lambda_{\text {maks }}\right)}\right.}\right] \times 100 \%$

Dari \% penangkap radikal dihitung persamaan garis regresi, untuk dicari menentukan harga konsentrasi efek 50\%-nya $\left(\mathrm{EC}_{50}\right)$ (Suryanto et al, 2003). Data yang diperoleh dari hasil persen penangkapan radikal bebas dianalisis secara statistik dengan ANAVA satu jalan untuk parametrik dilanjutkan dengan uji Tukey dengan taraf kepercayaan 99\%. Untuk non parametrik maka dilakukan analisis menggunakan uji Kruskal-Wallis dan uji Mann-Whitney. 


\section{HASIL DAN PEMBAHASAN}

\section{Penyarian dan Fraksinasi}

Penyarian daun Binahong dilakukan dengan metode infundasi karena flavonoid yang terdapat dalam tanaman kebanyakan dalam bentuk glikosida flavonoid yang bersifat polar sehingga penyariannya dapat menggunakan air panas. Hidrolisis dengan menggunakan $\mathrm{HCl} 2 \mathrm{~N}$ bertujuan untuk memecah ikatan antara gugus gula (glikon) dan gugus bukan gula (aglikon) pada glikosida. Hasil hidrolisis difraksinasi dengan eter. Senyawa aglikon akan masuk dalam fase eter, yang lebih polar akan masuk ke fase asam.

\section{Uji Pendahuluan Adanya Flavonoid}

Uji pendahuluan dengan uap amonia dan Uji KLT dengan fase diam silika gel F 254; Fase gerak:BAW (n-butanol:asam asetat:air) (4:1:5 v/v, fase atas); deteksi : UV 366.

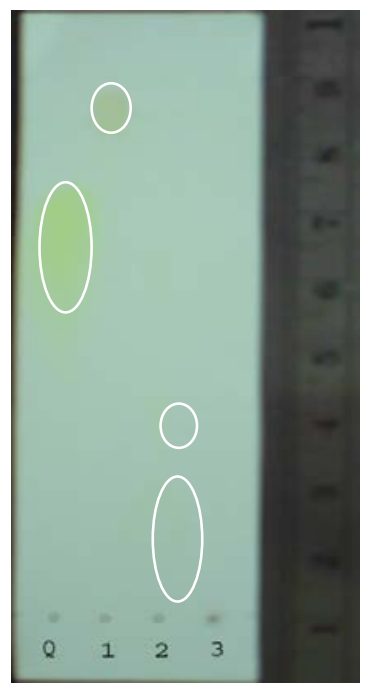

sebelum diuapi amonia

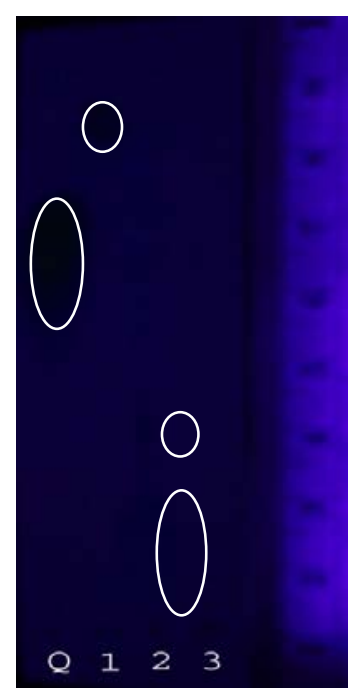

di bawah UV 366

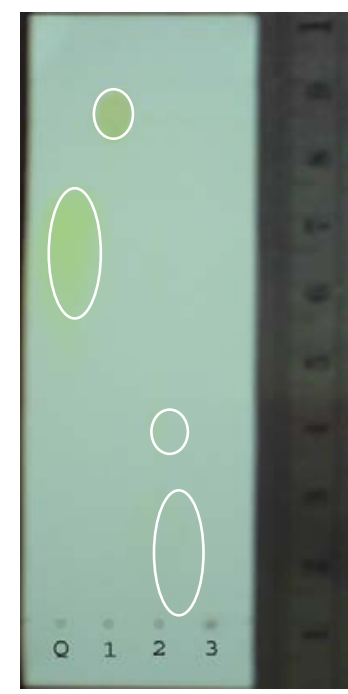

setelah diuapi amonia

Gambar 1. Hasil kromatogram quersetin (1), fraksi eter hasil hidrolisis infusa (2), infusa (3) dan fraksi air asam (4)

Tabel I. Data Rf kromatogram quersetin, fraksi eter hasil hidrolisis, infusa, dan fraksi air asam pada uji pendahuluan adanya flavonoid dengan Kromatografi Kertas menggunakan fase gerak BAW (4:1:5)

\begin{tabular}{|c|c|c|c|c|c|}
\hline \multirow[b]{2}{*}{ Totolan } & \multirow[b]{2}{*}{$\mathbf{R f}$} & \multicolumn{2}{|c|}{ Pengamatan mata } & \multicolumn{2}{|c|}{ UV 366} \\
\hline & & $\begin{array}{c}\text { Tanpa } \\
\text { perlakuan }\end{array}$ & Diuapi ammonia & $\begin{array}{c}\text { Tanpa } \\
\text { perlakuan }\end{array}$ & Diuapi ammonia \\
\hline Quersetin & 0,69 & Kuning & Kuning & Kuning & Kuning \\
\hline $\begin{array}{c}\text { Hasil } \\
\text { hidrolisis }\end{array}$ & 0,91 & Coklat & Kuning & Coklat & Coklat \\
\hline Infusa & $\begin{array}{l}0,20 \\
0,40\end{array}$ & $\begin{array}{l}\text { Kuning pucat } \\
\text { Kuning pucat }\end{array}$ & $\begin{array}{l}\text { Kuning pucat } \\
\text { Kuning pucat }\end{array}$ & $\begin{array}{l}\text { Biru } \\
\text { Biru }\end{array}$ & $\begin{array}{l}\text { Biru } \\
\text { Biru }\end{array}$ \\
\hline $\begin{array}{c}\text { Air } \\
\text { asam }\end{array}$ & - & - & - & - & - \\
\hline
\end{tabular}


Dari Tabel I diatas fraksi eter hasil hidrolisis infusa daun binahong terdapat aglikon flavonoid. Pada infusa terdapat dua bercak sehingga terdapat 2 senyawa glikon yang berbeda polaritasnya. Penarikan air oleh natrium sulfat anhidrat optimal yang ditunjukkan dengan tidak adanya bercak pada fraksi air asam (fraksi tidak larut eter). Terjadinya warna kuning menunjukkan adanya senyawa flavonoid. Timbulnya warna kuning tersebut disebabkan oleh adanya pembentukan struktur kuinoid pada cincin B yang mengandung ikatan rangkap terkonjugasi yang lebih panjang (Robinson, 1991). Berdasarkan Yang et al, 2008 kandungan quersetin dalam daun binahong sekitar $0,6 \%$.

\section{Uji Kualitatif Aktivitas Antioksidan dengan Asam Fosfomolibdat}

Uji kualitatif antioksidan dilakukan pada infusa, fraksi eter hasil hidrolisis infusa dan quersetin dengan asam fosfomolibdat. Terbentuknya warna biru menunjukkan adanya aktivitas antioksidan. Reaksi yang terjadi :
Flavonoid

$2 \mathrm{MoO}_{3}$

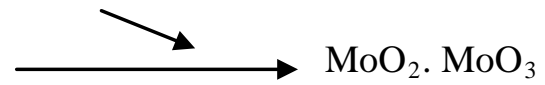

Gambar 2. Reaksi Uji Aktivitas antioksidan dengan Asam Fosfomolibdat

\section{Uji Aktivitas Penangkapan Radikal Bebas DPPH}

Uji aktivitas penangkapan radikal bebas dengan metode DPPH (1,1-difenil-2pikrilhidrazil). Mekanisme reaksi antara senyawa uji dan DPPH yaitu molekul radikal DPPH akan bereaksi dengan atom hidrogen yang dilepaskan oleh senyawa uji sehingga senyawa 1,1-difenil-2pikrilhidrazil menjadi berkurang intensitas warna ungunya atau menjadi berwarna kuning sampai jernih. Pengurangan intensitas warna ungu disebabkan oleh terbentuknya senyawa kompleks antara senyawa uji dengan DPPH. Aktivitas antioksidan quersetin sebagai penangkap radikal bebas DPPH dinyatakan dengan nilai persen penangkapan radikal bebas.

Tabel II. Persentase penangkapan radikal bebas DPPH dan nilai $\mathrm{EC}_{50}$ oleh quersetin pada berbagai konsentrasi

\begin{tabular}{|c|c|c|c|c|c|c|}
\hline \multicolumn{5}{|c|}{ \% Penangkapan radikal bebas } & \multirow[b]{2}{*}{ Persamaan regresi linear } & \multirow[b]{2}{*}{$\begin{array}{c}E C_{50} \\
(\mu \mathrm{g} / \mathrm{ml})\end{array}$} \\
\hline $\begin{array}{c}1 \\
\mu g / m l\end{array}$ & $\begin{array}{c}2 \\
\mu \mathrm{g} / \mathrm{ml}\end{array}$ & $\begin{array}{c}3 \\
\mu \mathrm{g} / \mathrm{ml}\end{array}$ & $\begin{array}{c}4 \\
\mu \mathrm{g} / \mathrm{ml}\end{array}$ & $\begin{array}{c}5 \\
\mu g / m l\end{array}$ & & \\
\hline 25,00 & 39,25 & 45,98 & 66,64 & 77,33 & $Y=13,005 X+11,425$ & 2,966 \\
\hline 25,91 & 44,04 & 52,85 & 72,93 & 69,43 & $Y=11,593 X+18,253$ & 2,738 \\
\hline 24,61 & 43,65 & 53,50 & 71,76 & 82,25 & $Y=14,339 X+12,137$ & 2,641 \\
\hline 26,42 & 42,88 & 48,58 & 70,59 & 73,32 & $Y=12,151 X+15,905$ & 2,806 \\
\hline 26,68 & 45,59 & 56,61 & 71,63 & 82,77 & $Y=13,822 X+15,190$ & 2,518 \\
\hline 22,67 & 43,91 & 58,55 & 72,66 & 82,51 & $Y=14,843 X+11,531$ & 2,592 \\
\hline 23,06 & 42,10 & 56,61 & 72,28 & 81,22 & $Y=14,650 X+11,104$ & 2,655 \\
\hline \multicolumn{6}{|c|}{ Rerata } & 2,702 \\
\hline \multicolumn{6}{|c|}{ SD } & 0,15 \\
\hline \multicolumn{6}{|c|}{$\mathrm{CV}$} & $5,55 \%$ \\
\hline
\end{tabular}

Dari tabel nilai $\mathrm{EC}_{50}$ nya dan diperoleh nilai rata - rata $\mathrm{EC}_{50}$ quersetin adalah 2,702 $\mu \mathrm{g} / \mathrm{ml}$.

Tabel III. Persentase penangkapan radikal bebas DPPH dan nilai $\mathrm{EC}_{50}$ oleh fraksi eter hasil hidrolisis infusa daun Binahong pada berbagai konsentrasi pada berbagai konsentrasi

\begin{tabular}{|c|c|c|c|c|c|c|c|}
\hline \multicolumn{6}{|c|}{ \% Penangkapan radikal bebas } & \multirow[b]{2}{*}{ Persamaan regresi linear } & \multirow[b]{2}{*}{$\begin{array}{c}\mathrm{EC}_{50} \\
\mu \mathrm{g} / \mathrm{ml}\end{array}$} \\
\hline $\begin{array}{c}50 \\
\mu \mathrm{g} / \mathrm{ml}\end{array}$ & $\begin{array}{c}75 \\
\mu \mathrm{g} / \mathrm{ml}\end{array}$ & $\begin{array}{c}100 \\
\mu \mathrm{g} / \mathrm{ml}\end{array}$ & $\begin{array}{c}125 \\
\mu \mathrm{g} / \mathrm{ml}\end{array}$ & $\begin{array}{c}150 \\
\mu \mathrm{g} / \mathrm{ml}\end{array}$ & $\begin{array}{c}200 \\
\mu \mathrm{g} / \mathrm{ml}\end{array}$ & & \\
\hline 10,37 & 16,83 & 21,22 & 26,22 & 29,15 & 40,24 & $\mathrm{Y}=0,1918 \mathrm{X}+1,627$ & 252,21 \\
\hline 13,05 & 17,20 & 24,15 & 26,95 & 30,36 & 41,95 & $Y=0,1881 X+3,664$ & 246,34 \\
\hline 14,27 & 15,85 & 21,46 & 24,27 & 30,85 & 40 & $Y=0,1779 X+3,694$ & 260,29 \\
\hline 12,44 & 18,54 & 22,32 & 25,61 & 28,17 & 45,24 & $Y=0,2022 X+1,798$ & 238,39 \\
\hline \multicolumn{7}{|c|}{ Rerata } & 249,31 \\
\hline \multicolumn{7}{|c|}{ SD } & 9,26 \\
\hline \multicolumn{7}{|c|}{$\mathbf{C V}$} & 3,71 \\
\hline
\end{tabular}


Dari Tabel II dan III dapat diketahui nilai $\mathrm{EC}_{50}$ quersetin lebih kecil dibandingkan dengan $\mathrm{EC}_{50}$ fraksi eter hasil hidrolisis infusa daun Binahong. Hal ini menunjukkan bahwa quersetin mempunyai kemampuan menangkal radikal bebas lebih besar dari fraksi eter hasil hidrolisis daun Binahong. Potensi quersetin 88,94 kali lebih besar dibandingkan dengan sampel fraksi eter hasil hidrolisis daun Binahong.

Hasil uji distribusi normal tersebut didapatkan harga signifikansi sebesar 0,059. Harga yang diperoleh lebih besar dari 0,05 sehingga dapat disimpulkan bahwa data terdistribusi normal. Uji homogenitas varian dengan Uji Levene diperoleh harga signifikansi 0,003 lebih kecil dari 0,05 disimpulkan tidak homogen. Karena tidak homogen maka dilanjutkan dengan uji analisis statistik non parametrik menggunakan Uji Kruskal Wallis dengan taraf kepercayaan 95\%. Data Uji Kruskal Wallis.

Dari Uji Kruskal Wallis di atas diperoleh harga signifikansi 0,008 yang lebih kecil dari 0,05 yang artinya bahwa pada berbagai kelompok perlakuan terdapat perbedaan yang bermakna. Kemudian dilanjutkan dengan Uji Mann Whitney diperoleh harga signifikansi sebesar 0,006 yang lebih kecil dari 0,05 yang berarti terdapat perbedaan yang bermakna nilai $\mathrm{EC}_{50}$ antara quersetin dan sampel fraksi eter hasil hidrolisis infusa daun Binahong.

\section{KESIMPULAN}

Quersetin dan fraksi eter hasil hidrolisis infusa daun Binahong (Anredera cordifolia (Ten.) Steenis) memiliki aktivitas antioksidan pada semua konsentrasi uji. Harga $\mathrm{EC}_{50}$ pada quersetin sebesar $2,702 \mu \mathrm{g} / \mathrm{ml}$, fraksi eter hasil hidrolisis infusa daun Binahong (Anredera cordifolia (Ten.) Steenis) sebesar 249,31 $\mu \mathrm{g} / \mathrm{ml}$. Terdapat perbedaan yang bermakna harga $\mathrm{EC}_{50}$ antara quersetin dan fraksi eter hasil hidrolisis infusa daun Binahong (Anredera cordifolia (Ten.) Steenis),

\section{SARAN}

Perlu dilakukan penelitian tentang aktivitas penangkapan radikal bebas DPPH dengan menggunakan penyarian yang lain dan metode lain, selain DPPH.

\section{DAFTAR PUSTAKA}

Chuang, M. T., Lin, Y. S., Hou, W. C. 2007. Ancordin The Major Rhizome Protein Of Madeira vine, With Trypsin Inhibitory and Stimulatory Activities in Nitrit Oxide Production. Peptides. 28 (6):1311-6.

Dalimartha dan Soedibyo, M. 1999. Awet Muda dengan Tumbuhan Obat dan Diet Suplemen. 1-8. Trubus Agriwidya. Semarang.

Hanasakti, Y., Ogawa, S., Fukui, S. 1994. The Corelation Between Active Oxygen, Scaveging and Antioxidantive Effect of Flavonoids, Free Radical Biol. Med., 16: 845-850.

Hernani dan Rahardjo. 2005. Tanaman Berkhasiat Antioksidan. Cetakan Pertama. Penebar Swadaya. Jakarta.

Kumalaningsih. 2006. Antioksidan Alami. Penangkal Radikal Bebas. 3-22. Trubus Agrisarana. Surabaya.

Moura-Letts, G., Villegas, L. F., Marcalo, A., Vaisberg, A. J., Hammon, G. B. 2006. In Vivo Wound-Healing Activity of Oleanolic Acid Derived from The Acid Hydrolysis of Anredera Diffusa. J. Nat. Prod. Jun. 69 (6): 978-9.

Rachmawati, S. 2008. Studi Makroskopi, Mikroskopi dan Skrining Fitokimia Daun Anredera cordifolia (Ten.) Steenis. Thesis. Airlangga University. Surabaya.

Son and Lewis. 2002. Free Radical Scavenging and Antioxidative Activity of Coffeic Acid Amide and Ester Analoges; Structur Activity Relationship. J. Agric. Food Chemi. 50. 469. Cornell University. Ithaca. New York.

Sunarni, T., Suwidjiyo Pramono dan Ratna Asmah. 2007. Flavonoid Antioksidan Penangkap Radikal dari Daun Kepel 
(Stelechocarpus burahol (Bl.) Hook f. \& Th.). Majalah Farmasi Indonesia. 18 (3). 111-116.

Suryanto Edy, Raharjo, S., Trenggono and Sastrohanodjojo. 2003. Singlet Oxygen Quenching Effect of Andaliman (Zanthoxylum acanthopodium DC) Extract In Light-Induced Lipid Oxidation, Final Report Research Grant $9^{\text {th }}$ Award (2002)
Research Project Period (FebruaryDecember 2003). 330. Universitas Gadjah Mada. Yogyakarta.

Yang, R.Y., Shou Lin, George Kuo. 2008. Original Article Content and Distribution of Flavonoid Among 91 Edible Plant Species. Asia. Pac. J. Clin. Nutr. 17 (S1). 275-279. 
